\title{
Adaptation of Sport Brand Personality Scale to Turkish
}

\author{
İlyas Görgüt ${ }^{1, *}$, Ayşe Feray Özbal ${ }^{2}$ \\ ${ }^{1}$ School of Physical Education and Sport, Kütahya Dumlupınar University, Turkey \\ ${ }^{2}$ School of Physical Education and Sport, Kastamonu University, Turkey
}

Copyright $\mathrm{O} 2018$ by authors, all rights reserved. Authors agree that this article remains permanently open access under the terms of the Creative Commons Attribution License 4.0 International License

\begin{abstract}
Validity and reliability of Turkish form of sport brand personality scale, which was developed by Mitsis and Leckie (2016), was presented in this study. Scale was designed to reflect the impact of individuals' favorite athletes on them in other words the strength of the role model factor. In study, participants were tried to reach through an online form on voluntary basis and participants were included into the study in two stages as pilot and main study. After the incorrect and incompletely filled scale forms had been taken out, 107 people were taken for the pilot study and 326 people were taken for the validity and reliability of the study, in total 433 people were taken into account for the statistical procedures. When the educational status of participants were asked in the study; it was stated that, 1 of participants was literate, 2 of participants were primary school, 6 of participants were secondary school, 69 of participants were high school, 300 of participants were university graduate and 55 of participants were undergraduate. When we look at age distribution of the participants, $10.6 \%$ of them were in $14-19$ age group, $37.4 \%$ of them were in $20-25$ age group, $20.6 \%$ of them were in $26-31$ age group, $14.3 \%$ of them were in $32-37$ age group, $9.5 \%$ of them were in $38-43$ age group, $5.3 \%$ of them were in $44-49$ age group, $2.1 \%$ of them were in 50-55 age group and .2\% of them were in 56 age and above group. For the Turkish adaptation of scale, language validity was provided through expert opinion. Validity of scale was assessed with confirmatory factor analysis and reliability of scale was assessed with split-half reliability methods. For the six subscales, it was seen that fit indices were in acceptable level for $\mathrm{X}^{2} / \mathrm{df}$, RMSEA, RFI, GFI, AGFI and in perfect level for CFI, NNFI, NFI, IFI. In conclusion, the internal consistency for all scale was .95 and for the six subscales respectively were $.91, .86, .86, .84, .77$ and .90 . In conclusion, obtained data by the application of Turkish form of scale showed that adapted scale having six subscales, 19 items and 7 Likert type scoring tool, was a valid and reliable scale.
\end{abstract}

Keywords Sport, Brand, Personality, Scale, Validity, Reliability

\section{Introduction}

Product variety and rapid movement of capital in today's globalized world have forced companies to apply different marketing strategies. Companies have been designing their human resources in accordance with this and try to implement their in-service trainings in accordance with this. Taking the individual directly into the center and doing projections considering his or her tendencies are among the goals of these trainings. Particularly, the personality, habits and attitudes of individuals, and their role models constitute the target audience and majority of these studies.

Personality is defined as distinct characteristics peculiar to a person; all of the spiritual and moral qualities; and all of the habits and behaviors of a person or individual acquired in social life [1]. Robbins and Judge [2] defined personality as the dynamic organization within the individual of those psychophysical systems that determine his unique adjustments to his environment. Özarslan [3] stated it as all of the distinct, stable and consistent characteristics of the individual. Sudak (2011) defined personality it as integrity of unique, decisive and consistent behaviors that are revealed with stimulation, feeling and opinions and with learning and beliefs [4].

Personality is considered as combination of various physical and psychological characteristics. On the other hand, as it is a product of heredity and environment, individuals living in the same neighborhood are expected to have some common points that significantly reflect their personalities [5]. In general, personality of an individual includes the combination of all characteristics including physical appearance in addition to regularity of his/her attitudes and experiences [6]. Finally, personality can be defined as a unique consistent and structured relationship type that distinguishes the individual from others he or she is in communication both in terms of his or her inner world and interactions that reflect all characteristics of the individual. [7].

Personality of an individual is represented by his or her own features, feelings, thoughts and motives that catalyze them in a permanent or temporary way, and consists of some characteristics [8]. Thus, the existence of various 
personality types can easily be understood from abovementioned definitions. These personality characteristics were analyzed under four titles as analytic personality which refers to people who focus on details, are competitive, and open to trying new things; showman personality which refers to people who are fond of attracting attention of others, speak fluently, and who focus on important aspects of sports competitions; dominant personality referring to people who never gets tired, are willing to lead others, ambitious for significant successes, and are sometimes nervous; and conciliating personality which refers to people who can effectively develop communication with others by Ioan and Mihaela [9].

Personality plays an important role in all areas of life. One of these areas is sports. It is possible to mention about a strong relationship between personality and sports. Especially as the participation in sports can affect personality development and on the other hand, that personality development affects participation to physical activities and sports reveals the mutual relationship between personality and participation in sports [10]. Thus, people who do sports are thought to be affected positively from both situations. Success and competition is the focus point of every athlete. Earning money, getting a higher status or experiencing success at the top can be counted among the goals of athletes as well. Although many athletes have the same goals, each individual commits success differently in accordance with his or her personality traits [11]. This expression leads us to the concept of role model based on various theories including social cognitive theory, role theory, role definition theory and social comparison theory [12]. A role model can be defined as, "an individual who is perceived as exemplary, or worthy of imitation" [13]. Individuals start behaving in accordance with role models they choose. For example, they wear or eat the same as the athlete they imitate, in other words, they reveal behavioral changes according to their role models. The changed behavior warns role model while it attracts the observers, and it creates permanent images and offers opportunities [14]. The concepts that are mentioned in previous research showed that role models had at least three characteristics such as outstanding performance, worthy of imitation and similarity [15]. Superior performances of athletes are adopted by people who follow them and are tried to be imitated. Furthermore, regarding the fact that sports supports the moral qualities and ethical principles of sports lovers, it is considered to be an important moral role model for others [16]. For this reason, in order to provide commercial reliability and effectiveness, famous athletes are exploited in advertisements. This is a worldwide preferred common application which organizations and marketing experts particularly focus on. This is because the famous athletes' being in the public eye affects all masses regardless to age and gender. By this way, the attitudes and behaviors of famous athletes attract the young and thus they consider those athletes as dynamic people with good qualities [17].
In conclusion, successful athletes are considered as effective role models that can inspire from children to adolescents to participate in sports and physical activities or be in sports places [18]. For this reason, the existence of teams and athletes with a high amount of fans makes it necessary to identify and measure the expectations of sports industry that has become a gross market all around the world. Namely, in addition to the studies that promote sports, the effect of athletes on individuals and the level of this effect have a significant role in stock and marketing strategies of companies and activities leading those strategies. For this reason, this study aims to adapt the "Sport Brand Personality Scale" into Turkish which is thought to provide the required data to researchers and the units working on strategy development.

\section{Materials and Methods}

The adaptation process of "Sport Brand Personality Scale" was conducted through following all of the scientific steps including language validity, piloting, reliability and validity studies that are all necessary for the adaptation of a scale.

\subsection{Participants}

The study consists of two steps. During the first step, participants from different levels of society were reached through the online form of the scale. 107 people were included in piloting of the scale during this step, and 16 people who did not fill in the scale appropriately were excluded from the study. As for the second step, 326 people who were reached online as well were included in the reliability and validity studies of data collection tool, and answers of 12 people were excluded from the study. The remaining number, 314 , is considered to be sufficient for adaptation studies. There are various suggestions in literature in terms of the number of participants in adaptation studies. Tabachnick and Fidell [19] suggested at least 300 participants for factor analysis in a study. On the other hand, Bryman and Cramer [20] stated that a group that would be at least five to tenfold of items in a scale form should be included in adaptation process. As to Hair et al., [21] they stated that fivefold of items in a scale would be enough for deciding on the number of participants who would sample the during the adaptation studies.

\subsection{The Original Form That Was Used for Adaptation Study}

The scale that was going to be adapted into Turkish, "Sports Brand Personality Scale" was developed by Mitsis and Leckie [22]. The original version consists of six sub dimensions and 19 items. Alpha values was found to be .88 for Competitiveness; .92 for Prestige; .82 for 
Morality; .84 for Authenticity; .81 for Credibility; and .90 for Role model Influence, and 7 point Likert type was used in scoring the scale.

\subsection{Data Analysis and Procedure}

Before the adaptation process, the developers of the scale were reached through email, and required permissions and notifications about the scale were received. Then, the translation/retranslation process of the original scale was conducted and completed by experts in the field. Moreover, the scale was checked by other field experts in terms of semantic aspects, and seeing that there wasn't any shift in meaning from the original version, the Turkish form of the scale was decided to be used.

Since a new scale was not developed, appositeness of existing situation was sought. Confirmatory Factor Analysis (CFA) was made to find out whether the scale was appropriate for Turkish participants or not. Meydan and Şeşen [23] described CFA as a useful method in terms of testing whether existing data of a researcher would suit with the previously discovered original structure. The adaptive values regarding CFA such as $\mathrm{X}^{2} / \mathrm{df}$, RMSEA, CFI, NNFI, NFI, IFI, RFI, GFI and AGFI were examined through Lisrel 8.80 analysis program.

\section{Findings}

Table 1. Age/Gender Distribution of Participants

\begin{tabular}{|c|c|c|c|c|c|c|}
\hline \multirow{2}{*}{ Age } & \multicolumn{4}{|c|}{ Gender } & \multicolumn{2}{c|}{ Total } \\
\cline { 2 - 6 } & \multicolumn{2}{|c|}{ Male } & \multicolumn{2}{c|}{ Female } & \multicolumn{2}{c|}{} \\
\cline { 2 - 6 } 14-19 Years & 14 & 4.7 & 32 & 23.5 & 46 & 10.6 \\
\hline 20-25 Years & 106 & 35.7 & 56 & 41.2 & 162 & 37.4 \\
\hline 26-31 Years & 67 & 22.6 & 22 & 16.2 & 89 & 20.6 \\
\hline 32-37 Years & 46 & 15.5 & 16 & 11.8 & 62 & 14.3 \\
\hline 38-43 Years & 35 & 11.8 & 6 & 4.4 & 41 & 9.5 \\
\hline 44-49 Years & 20 & 6.7 & 3 & 2.2 & 23 & 5.3 \\
\hline 50-55 Years & 8 & 2.7 & 1 & .7 & 9 & 2.1 \\
\hline 56 Years and above & 1 & .3 & 0 & .0 & 1 & .2 \\
\hline Total & 297 & 100.0 & 136 & 100.0 & 433 & 100.0 \\
\hline
\end{tabular}

As it is shown in Table 1, the distribution of the participants in terms of the age variable varied between $37.4 \%$ and $.2 \%$. $10.6 \%$ of participants belonged to $14-19$ years group; 37.4 to $20-25$ group; $20.6 \%$ to $26-31$ group; $14.3 \%$ to $32-37$ group; $9.5 \%$ to $38-43$ group; $5.3 \%$ to $44-49$ group; $2.1 \%$ to $50-55$ group; and $.2 \%$ to ' 56 and above group.

Distributions of the participants in terms of their educational attainments are shown in Table 2. .2\% of the participants were just literate; $.5 \%$ of them were primary school graduate; $1.4 \%$ were secondary school graduate;
$15.9 \%$ of them were high school graduate; $69.3 \%$ were university graduate; and $12.7 \%$ were postgraduates.

Table 2. Education/Gender Distribution of Participants

\begin{tabular}{|c|c|c|c|c|c|c|}
\hline \multirow{2}{*}{$\begin{array}{c}\text { Educational } \\
\text { Attainment }\end{array}$} & \multicolumn{4}{|c|}{ Gender } & \multicolumn{2}{c|}{ Total } \\
\cline { 2 - 7 } & $n$ & $\%$ & $n$ & $\%$ & $n$ & $\%$ \\
\hline Literate & 0 & .0 & 1 & .7 & 1 & .2 \\
\hline Primary school & 2 & .7 & 0 & .0 & 2 & .5 \\
\hline Secondary School & 6 & 2.0 & 0 & .0 & 6 & 1.4 \\
\hline High School & 52 & 17.5 & 17 & 12.5 & 69 & 15.9 \\
\hline University & 195 & 65.7 & 105 & 77.2 & 300 & 69.3 \\
\hline Postgraduate & 42 & 14.1 & 13 & 9.6 & 55 & 12.7 \\
\hline Total & 297 & 100.0 & 136 & 100.0 & 433 & 100.0 \\
\hline
\end{tabular}

Table 3. Favorite Athlete/Gender Distribution of Participants

\begin{tabular}{|c|c|c|c|c|c|c|}
\hline \multirow{2}{*}{ Favorite Athlete } & \multicolumn{5}{|c|}{ Gender } & \multicolumn{2}{c}{ Total } \\
\cline { 2 - 6 } & \multicolumn{2}{|c}{ Male } & \multicolumn{2}{c|}{ Female } & \multicolumn{2}{c|}{} \\
\cline { 2 - 6 } & $n$ & $\%$ & $n$ & $\%$ & $n$ & $\%$ \\
\hline Emre Mor & 3 & 1.0 & 2 & 1.5 & 5 & 1.2 \\
\hline Zlatan Ibrahimoviç & 4 & 1.3 & 1 & .7 & 5 & 1.2 \\
\hline Selçuk Inan & 4 & 1.3 & 2 & 1.5 & 6 & 1.4 \\
\hline Burak Y1lmaz & 6 & 2.0 & 3 & 2.2 & 9 & 2.1 \\
\hline George Hagi & 8 & 2.7 & 2 & 1.5 & 10 & 2.3 \\
\hline Moussa Sow & 9 & 3.0 & 1 & .7 & 10 & 2.3 \\
\hline Neslihan Demir & 1 & .3 & 10 & 7.4 & 11 & 2.5 \\
\hline Quaresma & 9 & 3.0 & 3 & 2.2 & 12 & 2.8 \\
\hline Volkan Demir & 9 & 3.0 & 4 & 2.9 & 13 & 3.0 \\
\hline Demba Ba & 8 & 2.7 & 6 & 4.4 & 14 & 3.2 \\
\hline Lionel Messi & 13 & 4.4 & 3 & 2.2 & 16 & 3.7 \\
\hline Wesley Sneijder & 15 & 5.1 & 6 & 4.4 & 21 & 4.8 \\
\hline Arda Turan & 17 & 5.7 & 7 & 5.1 & 24 & 5.5 \\
\hline Fernando Muslera & 16 & 5.4 & 12 & 8.8 & 28 & 6.5 \\
\hline Alex De Souza & 20 & 6.7 & 11 & 8.1 & 31 & 7.2 \\
\hline Cristiano Ronaldo & 29 & 9.8 & 3 & 2.2 & 32 & 7.4 \\
\hline Other & 126 & 42.4 & 60 & 44.1 & 186 & 43.0 \\
\hline Total & 297 & 100.0 & 136 & 100.0 & 433 & 100.0 \\
\hline
\end{tabular}

Findings regarding the favorite athlete of the participants are shown in Table 3 . These findings revealed that the top five mostly preferred athletes respectively were Cristiano Ronaldo with 7.4\% (32 participants); Alex De Souza with $7.2 \%$ (31 participants); Fernando Muslera with $6.5 \%$ (28 participants); Arda Turan with 5.5\% (24 participants); and Wesley Sneijder with 4.8\% (21 participants).

Examining the favorite team distributions of the participants in Table 4, it could be seen that Galatasaray with 133 participants and 30.7\%; Fenerbahçe with 131 participants and 30.3\%; and Beşiktaş with 77 participants and $17.8 \%$ was the top three preferred teams. 
Table 4. Favorite Team/Gender Distribution of Participants

\begin{tabular}{|c|c|c|c|c|c|c|}
\hline \multirow{3}{*}{$\begin{array}{c}\text { Team } \\
\text { Galatasaray SK }\end{array}$} & \multicolumn{4}{|c|}{ Gender } & \multirow{2}{*}{\multicolumn{2}{|c|}{ Total }} \\
\hline & \multicolumn{2}{|c|}{ Male } & \multicolumn{2}{|c|}{ Female } & & \\
\hline & 92 & 31.0 & 41 & 30.1 & 133 & 30.7 \\
\hline Fenerbahçe SK & 87 & 29.3 & 44 & 32.4 & 131 & 30.3 \\
\hline Beşiktaş SK & 49 & 16.5 & 28 & 20.6 & 77 & 17.8 \\
\hline Does not support any team & 36 & 12.1 & 12 & 8.8 & 48 & 11.1 \\
\hline Other teams & 17 & 5.7 & 3 & 2.2 & 20 & 4.6 \\
\hline Handball Teams & 2 & .7 & 4 & 2.9 & 6 & 1.4 \\
\hline Foreign Football Teams & 4 & 1.3 & 0 & .0 & 4 & .9 \\
\hline Basketball Teams & 0 & .0 & 1 & .7 & 1 & .2 \\
\hline Volleyball Teams & 0 & .0 & 1 & .7 & 1 & .2 \\
\hline Total & 297 & 100.0 & 136 & 100.0 & 433 & 100.0 \\
\hline
\end{tabular}

Table 5. Findings Related to the Pilot Study

\begin{tabular}{|c|c|}
\hline & Corrected Item-Total Correlation \\
\hline Item 1 & .82 \\
\hline Item 2 & .74 \\
\hline Item 3 & .76 \\
\hline Item 4 & .72 \\
\hline Item 5 & .64 \\
\hline Item 6 & .83 \\
\hline Item 7 & .71 \\
\hline Item 8 & .73 \\
\hline Item 9 & .73 \\
\hline Item 10 & .72 \\
\hline Item 11 & .74 \\
\hline Item 12 & .80 \\
\hline Item 13 & .68 \\
\hline Item 14 & .66 \\
\hline Item 15 & .75 \\
\hline Item 16 & .74 \\
\hline Item 17 & .68 \\
\hline Item 18 & .72 \\
\hline Item 19 & .73 \\
\hline \multicolumn{2}{|c|}{ Internal Consistency: .95 } \\
\hline
\end{tabular}

As it can be seen in Table 5, distribution of adjusted total item correlations of pilot study varied between .64 and .83 .

Table 6. CFA Results for the Items in the Scale ${ }^{*}$

\begin{tabular}{|c|c|c|c|c|}
\hline Fit Indexes & Perfect Levels & Acceptable Threshold Levels & Research Findings & Result \\
\hline $\mathbf{X}^{2} / \mathbf{d f}$ & $\leq 3$ & $4-5$ & 3.24 & Acceptable Fit \\
\hline RMSEA & $\leq .05$ & $.05-.10$ & $0.082^{* *}$ & Acceptable Fit \\
\hline CFI & $\geq .95$ & $\geq .90$ & 0.97 & Perfect Fit \\
\hline NNFI & $\geq .95$ & $\geq .90$ & 0.96 & Perfect Fit \\
\hline NFI & $\geq .95$ & $\geq .90$ & 0.95 & Perfect Fit \\
\hline IFI & $\geq .95$ & $\geq .90$ & 0.97 & Perfect Fit \\
\hline RFI & $\geq .95$ & $\geq .90$ & 0.94 & Acceptable Fit \\
\hline GFI & $\geq .90$ & $\geq .85$ & 0.88 & Acceptable Fit \\
\hline AGFI & $\geq .90$ & $\geq .85$ & 0.85 & Acceptable Fit \\
\hline
\end{tabular}

"Resource: (Seçer, 2015, p. 122; Meydan and Şeşen, 2011, p.37; ** MacCallum et al., 1996, cited in: Hooper et.al, 2008, p. 54). 
According to first level confirmatory factor analysis results of scale form that consisted of 19 items, values of $\mathrm{X}^{2} / \mathrm{df}$, RMSEA, RFI, GFI and AGFI were at "acceptable level" whereas CFI, NNFI, NFI and IFI, values were at "perfect level". Path diagram of the first level confirmatory factor analysis is shown below.

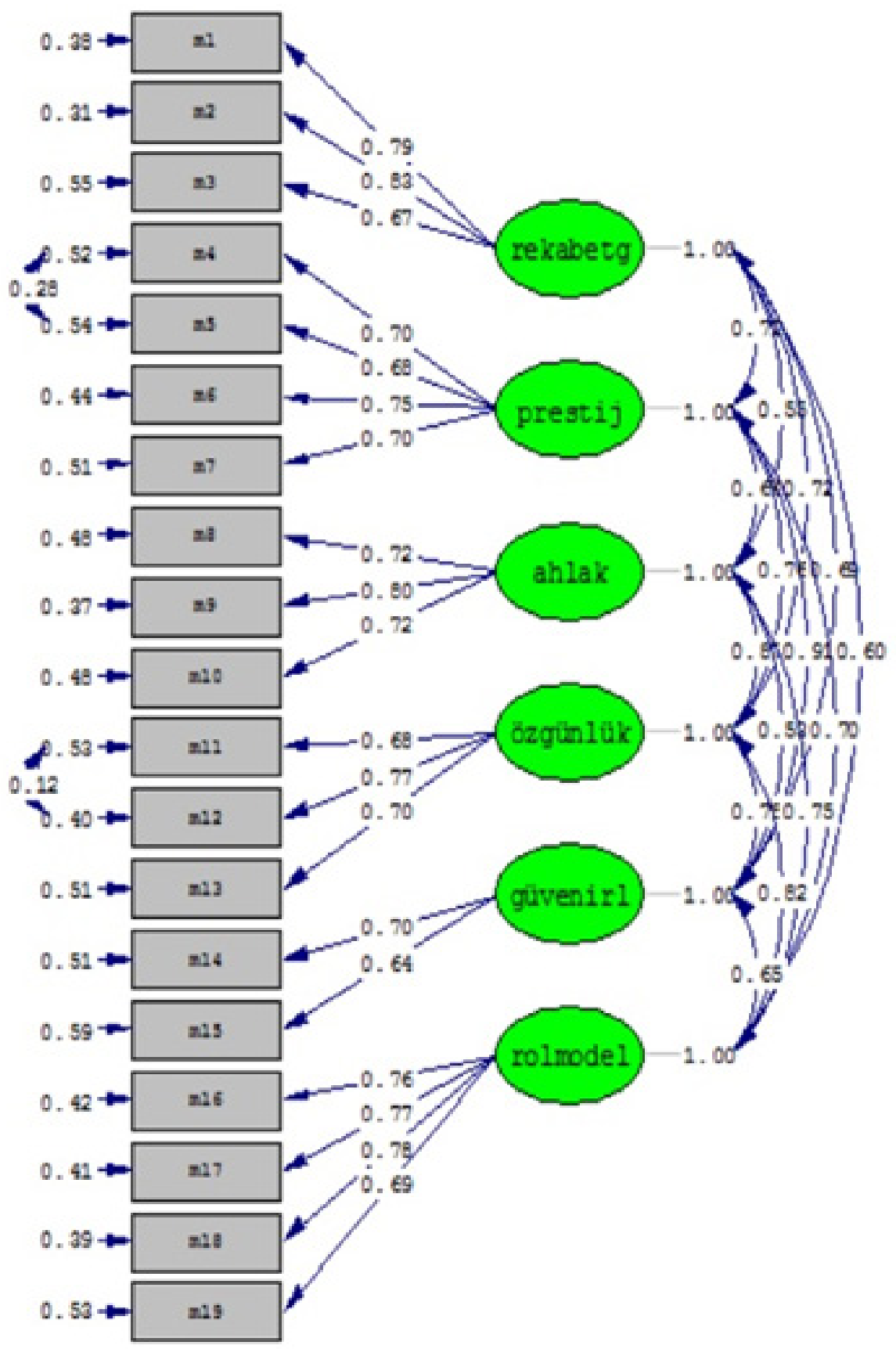

Chi-9quare $=431.24, d f=135, p-v a l u e=0.00000$, Rucsed $=0.092$

Figure 1. Path diagram of the first level confirmatory factor analysis 
As it can be seen from the path diagram, item factor loads varied between .64 and .83 .

Table 7. Reliability Results of Scale Adaptation

\begin{tabular}{|c|c|c|}
\hline Dimensions & Internal consistency & Split-half reliability \\
\hline Competitiveness & .91 & .91 \\
\hline Prestige & .86 & .90 \\
\hline Morality & .86 & .85 \\
\hline Authenticity & .84 & .90 \\
\hline Credibility & .77 & .78 \\
\hline Role Model Influence & .90 & .91 \\
\hline Whole Scale & .95 & .96 \\
\hline
\end{tabular}

Table 7 reveals the reliability results of scale adaptation process. Whole scale internal consistency was found to be .95; and split half reliability of the whole scale was 0.96 . As for the sub dimensions, both internal consistency and split half reliability for competitiveness was $.91 / .91$; for prestige, it was .86/.90; for morality, .86/.85; for authenticity, .84/.90; for credibility, .77/.78; and for role model influence, they were found to be $.90 / .91$.

\section{Discussion and Conclusions}

Brand personality has been regarded as an instrumental and descriptive factor in identifying the preferences, attitudes and intentions of consumers, and developing their brand loyalty [24]. As personality in sports or the effect of athlete on fans has become an important factor, recent studies have focused on brand personality in sports, namely, the effect of athletes on consumption habits of fans. Some of these studies aim to develop scales that measure those attitudes. Since attitude is to approach to or withdraw from the objects, concepts or circumstances around us, and reflecting behaviors against them [25].It would provide some benefits for manufacturers in terms of identifying demands for their products. For this reason, scale development and adaptation studies are considered significant.

In their study focusing on existing criticisms, and aiming at reconsidering sports-brand personality literature and restating fundamentals of the brand personality term, Kang et al. [26] found out five factors (Agreeableness, Extraversion/Emotionality, Openness, Conscientiousness, and Honesty) that closely resemble human personality trait models structure. "Creative Behaviour Questionnaire III" the first version of which was developed by Popek (1990/2000) was revised by Bernacka [27] in accordance with the term of humanistic creative attitudes, and a form including 26 items under 2 sub dimensions as convenience/inconvenience in terms of personality traits area and algorithmic behavior/intuitional behavior in terms of cognitive area.

Developed by Eysenck and Eysenck [28] and updated in 1985, "Eysenck's Personality Inventory" that was created as a result of analysis of responses of more than 30000 participants is a scale that has been used in evaluating relatively independent personality dimensions. The other scales that were applied on athletes to find out personality traits were "The Iceberg Profile" that six sub dimensions developed by Morgan [29]; "Ten Item Personality Inventory (TIPI)" that was developed by Gosling et al., [30]; "Personality Traits of the Champions Questionnaires" developed by Sohrabi et.al., [31]; and "Eysenck's Personality Inventory" that was developed by Bowen (2013) [32].

The fundamental reason of adapting "Sport brand personality scale" that was developed by Tsiotsou [33] and was the original version of the scale adapted in present study, was to measure features that consumers associated with their favorite sports teams and find out personal traits regarding sports teams. It had five dimensions and 24 items. Although there are various scales all around the world focusing on sports brands and personality traits, there has been a need for such scales in Turkey as well. For this reason, in order to serve this aim, "sport brand personality scale" was adapted into Turkish and made available for Turkish researchers.

Adapted Turkish version of "Sport Brand Personality Scale" (Spor Marka Kişilik Ölçeği) consists of 6 sub dimensions and 19 items. That total item correlations of the scale were found to be between .64 and .83 showed that the values for the scale were at significantly acceptable levels. To conclude, "Sport Brand Personality Scale" can be said to be a reliable and valid scale for Turkish culture as it meets the requirements of internal consistency coefficients with more than .70 and total item correlation values more than .30 [34]. Moreover, it had adequate DFA fit indexes $[35,23,36]$. 
English Form of the Scale: Sport Brand Personality Scale

\begin{tabular}{|c|c|c|c|c|c|c|c|c|c|}
\hline $\begin{array}{l}\text { FACTOR/ } \\
\text { SUBSCALE }\end{array}$ & & ITEMS & $\begin{array}{c}\text { Strongly } \\
\text { DISAGREE }\end{array}$ & DISAGREE & Little Disagree & Undecided & $\begin{array}{l}\text { Little } \\
\text { Agree }\end{array}$ & Agree & Strongly Agree \\
\hline \multirow{3}{*}{ Competitiveness } & 1 & $\begin{array}{l}\text { Ambitious: My favourite athlete is determined to accomplish his or her } \\
\text { goals }\end{array}$ & 1 & 2 & 3 & 4 & 5 & 6 & 7 \\
\hline & 2 & Dynamic: My favourite athlete is self-motivated & 1 & 2 & 3 & 4 & 5 & 6 & 7 \\
\hline & 3 & Triumphant: My favourite athlete excels in competitions & 1 & 2 & 3 & 4 & 5 & 6 & 7 \\
\hline \multirow{4}{*}{ Prestige } & 4 & Multitudinous: My favourite athlete is supported by countless fans & 1 & 2 & 3 & 4 & 5 & 6 & 7 \\
\hline & 5 & Glorious: My favourite athlete is celebrated & 1 & 2 & 3 & 4 & 5 & 6 & 7 \\
\hline & 6 & Great : My favourite athlete is super & 1 & 2 & 3 & 4 & 5 & 6 & 7 \\
\hline & 7 & Honorary: My favourite athlete has received awards for distinction & 1 & 2 & 3 & 4 & 5 & 6 & 7 \\
\hline \multirow{3}{*}{ Morality } & 8 & $\begin{array}{l}\text { Principled: My favourite athlete is imbued with acceptable rules of } \\
\text { conduct }\end{array}$ & 1 & 2 & 3 & 4 & 5 & 6 & 7 \\
\hline & 9 & $\begin{array}{l}\text { Cultural: My favourite athlete develops and promotes the growth of } \\
\text { culture }\end{array}$ & 1 & 2 & 3 & 4 & 5 & 6 & 7 \\
\hline & 10 & $\begin{array}{l}\text { Ethical: My favourite athlete behaves in accordance with standards for } \\
\text { right practice }\end{array}$ & 1 & 2 & 3 & 4 & 5 & 6 & 7 \\
\hline \multirow{3}{*}{ Authenticity } & 11 & $\begin{array}{l}\text { Traditional: My favourite athlete has been around for many years and } \\
\text { handed down legends and customs }\end{array}$ & 1 & 2 & 3 & 4 & 5 & 6 & 7 \\
\hline & 12 & Uncompromising: My favourite athlete adheres to principal positions & 1 & 2 & 3 & 4 & 5 & 6 & 7 \\
\hline & 13 & Radical: My favourite athlete is open to changes and new ideas & 1 & 2 & 3 & 4 & 5 & 6 & 7 \\
\hline \multirow[b]{2}{*}{ Credibility } & 14 & Wealthy: My favourite athlete is rich and financially independent & 1 & 2 & 3 & 4 & 5 & 6 & 7 \\
\hline & 15 & $\begin{array}{l}\text { Influential: My favourite athlete has the capacity and power to exert } \\
\text { effects on others and their decisions }\end{array}$ & 1 & 2 & 3 & 4 & 5 & 6 & 7 \\
\hline \multirow{4}{*}{ Role model influence } & 16 & My favourite athlete provides a good model for me to follow & 1 & 2 & 3 & 4 & 5 & 6 & 7 \\
\hline & 17 & My favourite athlete leads by example & 1 & 2 & 3 & 4 & 5 & 6 & 7 \\
\hline & 18 & My favourite athlete sets a positive example for others to follow & 1 & 2 & 3 & 4 & 5 & 6 & 7 \\
\hline & 19 & My favourite athlete acts as a role model for me & 1 & 2 & 3 & 4 & 5 & 6 & 7 \\
\hline
\end{tabular}


Turkish Form of the Scale: Spor Marka Kişilik Ölçeği

\begin{tabular}{|c|c|c|c|c|c|c|c|c|c|}
\hline $\begin{array}{c}\text { FAKTÖR/ } \\
\text { ALTBOYUT }\end{array}$ & & MADDELER & \begin{tabular}{|c|} 
Tamamen \\
KATILMIYORUM \\
\end{tabular} & KATILMIYORUM & $\begin{array}{c}\text { Biraz } \\
\text { KATILMIYORUM }\end{array}$ & Kararsızım & $\begin{array}{c}\text { Biraz } \\
\text { Kat1lyorum }\end{array}$ & Kat1liyorum & $\begin{array}{c}\text { Tamamen } \\
\text { Kat1liyorum }\end{array}$ \\
\hline \multirow{3}{*}{ Rekabet Gücü } & 1 & Hırs: Favori sporcum hedeflerini gerçekleştirmede kararlıdır. & 1 & 2 & 3 & 4 & 5 & 6 & 7 \\
\hline & 2 & Dinamik Favori sporcum kendi kendini motive eder. & 1 & 2 & 3 & 4 & 5 & 6 & 7 \\
\hline & 3 & Galip: Favori sporcum yarışmalarda başarılıdır. & 1 & 2 & 3 & 4 & 5 & 6 & 7 \\
\hline \multirow{4}{*}{ Prestij } & 4 & $\begin{array}{llll}\text { Kalabalık: Favori sporcum sayısız hayranı tarafindan } \\
\text { desteklenir. }\end{array}$ & 1 & 2 & 3 & 4 & 5 & 6 & 7 \\
\hline & 5 & Ünlü: Favori sporcum ünlüdür. & 1 & 2 & 3 & 4 & 5 & 6 & 7 \\
\hline & 6 & Mükemmel: Favori sporcum süperdir. & 1 & 2 & 3 & 4 & 5 & 6 & 7 \\
\hline & 7 & Onur: Favori sporcum saygınlığından ötürü ödüller alır. & 1 & 2 & 3 & 4 & 5 & 6 & 7 \\
\hline \multirow{3}{*}{ Ahlak } & 8 & $\begin{array}{l}\text { İlkeli: Favori sporcum kabul edilebilir davranış kurallarını } \\
\text { aşlar. }\end{array}$ & 1 & 2 & 3 & 4 & 5 & 6 & 7 \\
\hline & 9 & $\begin{array}{l}\text { Kültürel: Favori sporcum kültürel gelişimi destekler ve teşvik } \\
\text { eder. }\end{array}$ & 1 & 2 & 3 & 4 & 5 & 6 & 7 \\
\hline & 10 & $\begin{array}{l}\text { Etik: Favori sporcum doğru uygulamalar yapabilmek için } \\
\text { standartlarla uyumlu hareket eder. }\end{array}$ & 1 & 2 & 3 & 4 & 5 & 6 & 7 \\
\hline \multirow{3}{*}{ Özgünlük } & 11 & $\begin{array}{l}\text { Geleneksel: Favori sporcum hep göz önündedir. Gelenekleri ve } \\
\text { efsaneleri kuşaktan kuşağa ulaştırır. }\end{array}$ & 1 & 2 & 3 & 4 & 5 & 6 & 7 \\
\hline & 12 & İnatçı: Favori sporcum prensiplerine bağlıdır. & 1 & 2 & 3 & 4 & 5 & 6 & 7 \\
\hline & 13 & $\begin{array}{l}\text { Radikal: Favori sporcum değişikliklere ve yeni fikirlere } \\
\text { açiktır. }\end{array}$ & 1 & 2 & 3 & 4 & 5 & 6 & 7 \\
\hline \multirow[b]{2}{*}{ İnanılırlık } & 14 & Varlıkı: Favori sporcum zengin ve mali açıdan bağımsızdır. & 1 & 2 & 3 & 4 & 5 & 6 & 7 \\
\hline & 15 & $\begin{array}{l}\text { Etkili: Favori sporcum başkalarına ve onların kararlarına etki } \\
\text { edecek güç ve kapasiteye sahiptir. }\end{array}$ & 1 & 2 & 3 & 4 & 5 & 6 & 7 \\
\hline \multirow{4}{*}{$\begin{array}{l}\text { Rol Model } \\
\text { Etkisi }\end{array}$} & 16 & Favori sporcum takip etmem için iyi bir rol modeldir. & 1 & 2 & 3 & 4 & 5 & 6 & 7 \\
\hline & 17 & Favori sporcum örnekler vererek yol gösterir. & 1 & 2 & 3 & 4 & 5 & 6 & 7 \\
\hline & 18 & $\begin{array}{l}\text { Favori sporcum başkalarının takip etmesi için olumlu bir duruş } \\
\text { sergiler. }\end{array}$ & 1 & 2 & 3 & 4 & 5 & 6 & 7 \\
\hline & 19 & Favori sporcum benim için rol model gibi davranır. & 1 & 2 & 3 & 4 & 5 & 6 & 7 \\
\hline
\end{tabular}




\section{REFERENCES}

[1] Türk Dil Kurumu (TDK). (2017). Personality. In 31.01.2017 Retrieved from: http://www.tdk.gov.tr/index.php?option=com_gts\&kelime= $\mathrm{K} \% \mathrm{C} 4 \% \mathrm{~B} 0 \% \mathrm{C} 5 \% 9 \mathrm{E} \% \mathrm{C} 4 \% \mathrm{~B} 0 \mathrm{~L} \% \mathrm{C} 4 \% \mathrm{~B} 0 \mathrm{~K}$

[2] Robbins, P. S., Judge, A. T. (2013). Organizational Behavior. (Çeviri Editör: İnci Erdem, Çeviren: Melek Tüz), Ankara: Nobel Yayın.

[3] Özarslan, M. (2010). “Örgütlerde iş tatmini ve kişilik tipi ilişkisi: vali yardımcılarına yönelik kuramsal ve uygulamalı bir araştırma”. Yayımlanmamış Doktora Tezi, Selçuk Üniversitesi, Sosyal Bilimler Enstitüsü, Konya.

[4] Sarığlu Uğur, S. (2016). Kişilik Tipolojilerine Göre Çalışanların Örgütsel Sessizlik Algılamaları: Kamu ve Özel Kesimde Bir Araştırma. Doktora Tezi, İnönü Üniversitesi, Sosyal Bilimleri Enstitüsü, Malatya.

[5] Kanniyan, A., George, A., Valiyakath, S. (2015). Personality Traits: An Analytical Study between Sedentary Males and Sports Males. Science, Movement and Health, 15 (1): 5-9.

[6] Schliermann, R., Stolz, I., \& Anneken, V. (2014). The Sports Background, Personality, Att Itudes, and Social Competencies of Coaches and Assistant Coaches in the Just Soccer Program for Pupils with Intellectual Disabilities. Human Movement, 15(3), 177-185.

[7] Çetin, N. G., \& Beceren, E. (2007). Lider Kişilik: Gandhi. Süleyman Demirel Üniversitesi Sosyal Bilimler Enstitüsü Dergisi. 3 (5) 110-132.

[8] Park, S. H., Kim, Y., \& Seo, W. J. (2015). Role of curiosity and openness to experience the big five traits on sport media consumption behaviours. South African Journal for Research in Sport, Physical Education and Recreation, 37(3), 153-167.

[9] Ioan, T. D., \& Mihaela, C. (2010). Personality and performance sport. Ovidius University Annals, Series Physical Education \& Sport/Science, Movement \& Health, 10(2).

[10] Laborde, S., Guillén, F., \& Mosley, E. (2016). Positive personality-trait-like individual differences in athletes from individual-and team sports and in non-athletes. Psychology of Sport and Exercise, 26, 9-13.

[11] West, J., Rhoden, C., Robinson, P., Castle, P., \& St Clair Gibson, A. (2016). How motivated are you? Exploring the differences between motivational profiles and personality traits. Sport and Exercise Psychology Review, 12(1), 28-42.

[12] Mutter, F., \& Pawlowski, T. (2014). Role models in sportsCan success in professional sports increase the demand for amateur sport participation? Sport Management Review, $17(3), 324-336$.

[13] Yancey, A. K. (1998). Building positive self-image in adolescents in foster care: The use of role models in an interactive group approach. Adolescence, 33(130), 253-268.

[14] Lyle, J. (2013). Role models, sporting success and participation: A review of sports coaching's ancillary roles.
International Journal of Coaching Science, 7(2), 25-40.

[15] Wicker, P., \& Frick, B. (2016). Recruitment and retention of referees in nonprofit sport organizations: The trickle-down effect of role models. VOLUNTAS: International Journal of Voluntary and Nonprofit Organizations, 27(3), 1304-1322. DOI 10.1007/s11266-016-9705-4

[16] Melin, R. (2014). Are Sportspersons Good Moral Role Models? Physical Culture and Sport. Studies and Research, 64(1), 5-17.

[17] Wong, M. C. M., Kwok, M. L. J., \& Lau, M. M. (2015). Spreading good words: the mediating effect of brand loyalty between role model influence and word of mouth. Contemporary Management Research, 11(4), 313.

[18] Adriaanse, J. A., \& Crosswhite, J. J. (2008, October). David or Mia? The influence of gender on adolescent girls' choice of sport role models. In Women's Studies International Forum (Vol. 31, No. 5, pp. 383-389). Pergamon.

[19] Tabachnick, B. G., \& Fidell, L. S. (2007). Using multivariate statistics (5th ed.). Boston, MA: Allyn \& Bacon.

[20] Bryman A, Cramer D. (2001). Quantitative Data Analysis with SPSS Release 1o for Windows, Routledge, London.

[21] Hair, J. F., Anderson, R. E., Tatham, R. L., \& Black, W. C. (1998). Multivariate data analysis (5th ed.). Upper Saddle River, NJ: Prentice-Hall.

[22] Mitsis, A., \& Leckie, C. (2016). Validating and extending the sport brand personality scale. Journal of Service Theory and Practice, 26(2), 203-221.

[23] Meydan, C.H. \& Şeşen, H. (2011). Yapısal Eşitlik Modellemesi AMOS Uygulamaları (1.Baskı). Ankara: Detay Yayıncilik.

[24] Karjaluoto, H., Munnukka, J., \& Salmi, M. (2016). How do brand personality, identification, and relationship length drive loyalty in sports? Journal of Service Theory and Practice, 26(1), 50-71.

[25] Güllü, M. \& Güçlü, M. (2009). Ortaöğretim öğrencileri için beden eğitimi dersi tutum ölçeği geliştirilmesi. Beden Eğitimi ve Spor Bilimleri Dergisi, 3(2).

[26] Kang, C., Bennett, G., \& Peachey, J. W. (2016). Five dimensions of brand personality traits in sport. Sport Management Review, 19(4), 441-453.

[27] Bernacka, R. (2009). Cognitive and emotional-motivational discrepancies in the functioning of constructive and apparent non-conformists. W: S. Popek i in. (red.). Psychologia twórczości-nowe horyzonty, 176-182.

[28] Eysenck, H.J. \& Eysenck, S.B.G. (1964). Manual of eysenck personality inventory. London: University of London Press.

[29] Morgan, W. P. (1980). Test of champions the iceberg profile. Psychology Today, 14(2), 92-108.

[30] Gosling, S. D, Rentfrow, P. J. \& Swann Jr, W. B. (2003). A very brief measure of the big five personality domain. Journal of Research in Personality, 37(6), 504-528.

[31] Sohrabi, F Atashak, S. \& Aliloo, M.M. (2011). Psychological Profile of Athletes in contact and non-contact. Middle-East Journal of Scientific Research, 9(5), 638-644. 
[32] Khan, B., Ahmed, A., \& Abid, G. (2016). Using the 'Big-Five' for Assessing Personality Traits of the Champions: An Insinuation for the Sports Industry.

[33] Tsiotsou, R. (2012),"Developing a scale for measuring the personality of sport teams", Journal of Services Marketing, Vol. 26 Iss 4 pp. 238 - 252

[34] Büyüköztürk Ş. (2007). Sosyal Bilimler İçin Veri Analizi El
Kitab1 (21. Bask1). Ankara: Pegem akademi yayınları.

[35] Seçer, İ. (2015). Psikolojik test geliştirme ve uyarlama süreci (1.Bask1). Ankara: An1 yayıncılık. ISSBN: 978-605-170-014-4

[36] Hooper, D., Coughlan, J., \& Mullen, M. (2008). Structural equation modelling: Guidelines for determining model fit. Articles, 2. 